\title{
Effect of desiccation during cold storage on planting stock quality and field performance in forest species
}

\author{
Didier Garriou ${ }^{\mathrm{a}, \mathrm{b}}$, Sabine Girard ${ }^{\mathrm{c}, \mathrm{d}}$, Jean-Marc Guehl ${ }^{\mathrm{d}}{ }^{*}$ and Benoît Généréa \\ a Division Ressources Génétiques et Plants Forestiers, Cemagref, domaine des Barres, 45290 Nogent sur Vernisson, France \\ ${ }^{\mathrm{b}}$ Institut Jules Guyot, Université de Dijon, Campus Montmuzard, BP. 138, 21004 Dijon, France \\ ${ }^{\mathrm{c}}$ Institut pour le Développement Forestier, 23 avenue Bosquet, 75007 Paris, France \\ ${ }^{\mathrm{d}}$ Équipe Bioclimatologie et Écophysiologie Forestière, Centre INRA de Nancy, 54280 Champenoux, France
}

(Received 17 May 1999; accepted 10 November 1999)

\begin{abstract}
Seedlings of pedunculate oak (Quercus robur L.), northern red oak (Quercus rubra L.) and Corsican pine (Pinus nigra ssp laricio var Corsicana) were lifted on November 18, January 27 and March 10. They were cold stored for 0,2 or 4 weeks in desiccating conditions (gunny bags, $1.4^{\circ} \mathrm{C}, 87 \% \mathrm{RH}$ ). An additional treatment consisted in a cold storage for 4 weeks in sealed polythene bags. Root growth potential (RGP), fine root electrolyte leakage (REL) and seedling water status variables were measured. Simultaneously, seedlings were outplanted. The seedlings lifted in November exhibited lower survival and RGP (except in pine) than those lifted in January and March. Cold storage for four weeks in sealed polythene bags did alter water status variables in none of the species, but decreased pine survival. Storage in gunny bags led to a desiccation in all plant components but in pine buds. In pine, RGP and survival after outplanting decreased with desiccation duration. In oaks, and namely pedunculate oak, desiccation lowered RGP, survival and growth after outplanting. In oaks, poor field survival and shoot dieback were associated with low fine root water content measured at the time of planting, and with low RGP. No satisfactory predictor of field survival or growth was found in pine.
\end{abstract}

seedling quality / lifting date / desiccation / field performance / root growth potential

Résumé - Effets du dessèchement au cours de la conservation au froid sur la qualité et la reprise après plantation de plants d'espèces forestières. Des plants de chêne pédonculé (Quercus robur L.), de chêne rouge d'Amérique (Quercus rubra L.) et de pin laricio de Corse (Pinus nigra ssp laricio var Corsicana) ont été arrachés au 18 novembre, au 27 janvier et au 10 mars. Ils ont été conservés au froid pendant 0,2 ou 4 semaines, en conditions desséchantes (sac de jute, $2{ }^{\circ} \mathrm{C}, 85 \% \mathrm{HR}$ ). Un traitement supplémentaire était constitué par des plants conservés durant 4 semaines en sac plastique fermé. La capacité de croissance racinaire (RGP), la perte relative en électrolytes (REL) ainsi que des variables relatives à l'état hydrique des plants ont été mesurées. Parallèlement, les plants ont été installés en plantation. RGP et la survie des plants arrachés en novembre étaient plus faibles que celles des plants arrachés en janvier ou mars. La conservation au froid pendant quatre semaines en sac plastique fermé n'a altéré les variables d'état hydrique pour aucune des trois espèces, mais a réduit la survie des pins. La conservation en sac de jute a conduit à un dessèchement de toutes les parties du plant, sauf les bourgeons du pin. Pour le pin, RGP et la survie après plantation ont diminué avec la durée du dessèchement. Pour les chênes, et notamment pour le chêne pédonculé, le dessèchement a réduit RGP, la survie et la croissance. Pour les chênes, une moindre survie et de fortes descentes de cime étaient associées à une teneur en eau des racines fines faible au moment de la plantation et à des faibles valeurs de RGP. Pour le pin aucun prédicteur fiable de la survie ou de la croissance n'a été trouvé.

qualité des plants / date d'arrachage / dessèchement / reprise après plantations / croissance racinaire

\footnotetext{
* Correspondence and reprints: Unité Écophysiologie Forestière, INRA Centre de Nancy, 54280 Champenoux, France, e-mail: guehl@nancy.inra.fr
} 


\section{INTRODUCTION}

Bareroot seedlings are widely used for reforestation in the temperate zone. For successful field establishment, seedlings have to overcome a "transplanting shock" which is primarily caused by plant water stress $[4,22$, 28]. This stress is caused by insufficient water supply from soil to roots after planting $[20,31,33]$ which may result in poor survival and slower growth [3, 8, 24, 33]. The recovery of a favourable physiological status requires an efficient initiation and elongation of new roots $[2,14,15,16]$. Root Growth Potential (RGP, a measure of the seedling intrinsic capacity of new root elongation) can be a useful indicator of outplanting performance, especially with respect to survival [35].

The physiological quality of planting stock can be endangered in post-cultural nursery operations (lifting, grading, storage, transport to planting site). During these operations, seedlings may be exposed to ambient conditions that can lead to desiccation $[11,28]$ and to reduced survival of coniferous $[7,8,13,17,29,34,38]$ and broadleaved [12, 18, 19, 30, 37] seedlings. Seedling physiology also varies over the lifting period from autumn to spring. Vigour and RGP were low when seedlings were lifted in early fall (see review by Camm et al. [5]). These changes have been associated to changes in dormancy intensity and stress resistance, especially frost hardiness. Maximum resistance generally occurs from early to mid-winter for coniferous [21] and broadleaved [26] species. Changes during winter in the resistance to desiccation of seedlings have poorly been characterised so far $[8,17]$. Root electrolyte leakage (REL, [27]) measurements, reflecting the membrane integrity of fine roots, have proven useful for assessing resistance to desiccation and its changes during winter [25]. However these changes have not been characterised on the basis of water status parameters so far.

The precise objectives of the present study were:

- To assess the effects of seedling desiccation during short duration cold storage (less than four weeks) on water status variables, REL, RGP as well as performance after outplanting (survival and growth). Such storage conditions without protection are to be distinguished from those characterising long term cold storage in bags. They may occur when planting is not possible immediately after lifting, e.g. for climatic reasons;

- To characterise changes during winter in the sensitivity to these desiccating conditions by considering different lifting dates;

- To evaluate the ability of water status variables, $R E L$ and $R G P$ for predicting performance after outplanting [23].

It must be emphasised that the short term (several weeks) storage conditions in desiccating conditions tested here are different from the long term (several months) cold storage conditions. In the latter case, storage procedures allowing to maintain an optimal seedling water status have clearly been defined [40]. Three major forest tree species were used: Northern red oak (Quercus rubra L.) and Corsican pine (Pinus nigra ssp laricio Poir. var Corsicana) which are considered as sensitive to transplanting and pedunculate oak (Quercus robur L.), a species expected to be less sensitive. Three lifting dates were considered from November to March.

\section{MATERIALS AND METHODS}

\subsection{Plant material and storage conditions}

Seedlings were grown in a nursery at Lordonnois in France (lat. $47^{\circ} 54^{\prime} \mathrm{N}$, long. $3^{\circ} 43^{\prime} \mathrm{E}$, elev. $160 \mathrm{~m}$ ). Twoyear-old pedunculate oak seedlings of "Loire Moyenne" provenance, two-year-old northern red oak seedlings of "North East France" provenance and three-year-old Corsican pine seedlings of "Sologne Vayrières" seed orchard were used. Seedlings were lifted on November 18 1996, January 27 and March 10 1997. Following lifting, seedlings were put in sealed polythene bags and delivered by van to Nogent-sur-Vernisson (lat. $47^{\circ} 50^{\prime} \mathrm{N}$, long. $2^{\circ} 45^{\prime} \mathrm{E}$, elev. $\left.147 \mathrm{~m}\right)$ within 2 hours $(100 \mathrm{~km})$ where they were washed to remove soil remains. Plant height, stem diameter (measured 0.5 and $3 \mathrm{~cm}$ above root collar, for pine and oaks respectively), number of first order lateral roots, dry weight and shoot to root dry weight ratio were assessed in the three species (table I).

Table I. Morphological traits of planting stock in the three species.

\begin{tabular}{lcccc}
\hline Species & $\begin{array}{c}\text { Initial } \\
\text { height }(\mathrm{cm})\end{array}$ & $\begin{array}{c}\text { Initial } \\
\text { Diameter }(\mathrm{mm})\end{array}$ & $\begin{array}{c}\text { Number of } \\
\text { first order roots }\end{array}$ & $\begin{array}{c}\text { Plant dry } \\
\text { weight (g) }\end{array}$ \\
\hline Northern red oak & 66.9 & 6.9 & 8.2 & 24.7 \\
Pedunculate oak & 70.3 & 9.4 & 15.5 & 39.0 \\
Corsican pine & 22.0 & 5.7 & 7.3 & 8.8 \\
\hline
\end{tabular}


For each lifting date and species, 640 seedlings were used. The following experimental treatments were distinguished:

(1) non stored control $(n=160)$,

(2) two week cold storage in gunny bags $(n=160)$,

(3) four week cold storage in gunny bags $(n=160)$,

(4) four week cold storage in sealed polythene bags (protected from desiccation, $n=160$ ).

In the cold store, seedlings were bundled (80 and 160 seedlings for oaks and pine seedlings, respectively). Then, they were set upright on opened metallic shelves. Gunny bags ( $25 \%$ porosity, $1.2 \mathrm{~mm}$ thickness) and polythene bags $(0.12 \mathrm{~mm}$ thickness, black inside and white outside) were used. The following ambient conditions prevailed in the cold store: total darkness, ambient temperature, $1.4^{\circ} \mathrm{C}\left( \pm 0.4^{\circ}\right)$; relative humidity, $87 \%( \pm 5 \%)$; Piche evaporation, $0.4 \mathrm{~mm} /$ day.

After each lifting date and storage duration, representative subsamples were taken for quality and performance assessments.

\subsection{Quality variables}

A subsample of 11 to 14 seedlings per treatment was taken at random from the bags. On each seedling, a series of quality variables was measured:

- Seedling weight loss ( $W L$, in \%) was calculated by comparing the weight of seedlings before $(W 0)$ and after $(W 1)$ storage for numbered seedlings:

$$
W L=\frac{W 0-W 1}{W 0} \times 100 .
$$

- Water content of various plant components was determined: the top $3 \mathrm{~cm}$ of the leading shoot (for oaks only), the base of the taproot (for oaks only), the very fine roots $(<1 \mathrm{~mm}$ diameter $)$, the apical buds and the needles (for pine only). For each component, fresh weight $(F W)$ and dry weight $\left(D W\right.$, oven drying at $105^{\circ} \mathrm{C}$ for 24 hours) were assessed. Water content (\%) was expressed as:

$$
\text { Water Content }=\frac{F W-D W}{D W} \times 100
$$

- Relative water content of root or needle (for pine) was also determined as:

$$
\text { Relative Water Content }=\frac{F W-D W}{T W-D W} \times 100 \text {. }
$$

$T W$ being the turgid weight obtained by saturation in deionised water for 24 hours in a cold chamber $\left(2{ }^{\circ} \mathrm{C}\right.$, in darkness).

- Fine root electrolyte leakage (REL) was assessed by the method of McKay [27]. For each seedling, four samples of fine roots $(1.5 \mathrm{~mm}$ diameter, $2 \mathrm{~cm}$ long) were taken and washed in two deionised baths. The samples were damped in $25 \mathrm{~mL}$ deionised water and shaken at room temperature for 24 hours. Then, conductivity of the solution $(\mathrm{Ci})$ was measured using a conductivity probe with temperature compensation. Samples were autoclaved to break cell membranes (at $110^{\circ} \mathrm{C}$ for $10 \mathrm{~min}$ utes). Total conductivity $(C t)$ was measured after sample cooling. Root electrolyte leakage ( $R E L$, in \%) was expressed as:

$$
R E L=\frac{C i-C w}{C t-C w} \times 100
$$

$C w$ being the conductivity of deionised water without any root.

- Water potential $\left(\Psi_{\mathrm{wp}}\right.$, pressure chamber model Skye $1400)$, osmotic potential ( $\pi$, vapour pressure osmometer Wescor 5500, Logan, Utah, USA) and turgor potential $\left(P=\Psi_{\mathrm{wp}}-\pi\right)$ were determined on one individual pine needle per seedling at the end of the storage periods, in darkness.

\subsection{Seedling performance}

Ten seedlings per treatment (excepted for oak stored in bags) were immediately shipped in sealed polythene bags to Nancy where they were planted in minirhizotrons (boxes of $3 \times 30 \times 70 \mathrm{~cm}$ with one transparent side to follow root growth). Minirhizotrons were filled with sphagnum peat and irrigated every second day. They were put in controlled conditions: $T=20^{\circ} \mathrm{C}$ day $/ 15^{\circ} \mathrm{C}$ night, $R H=60 \%$ day $/ 90 \%$ night, photoperiod $14 \mathrm{~h}$, photosynthetic flux radiation $=350 \mathrm{mmol} \mathrm{m}^{-2} \mathrm{~s}^{-1}$ and $\mathrm{CO}_{2}$ concentration $=440 \mu \mathrm{mol} \mathrm{mol} \mathrm{m}^{-1}$. Root growth potential (RGP) was defined as the length of visible new roots measured 42 days after planting [13].

Sixty other seedlings per treatment were root-pruned at $17 \mathrm{~cm}$ from root collar. Then, they were planted in nursery coldframe raised beds. Treatments were randomised in a four-block design, and planted in lines of five seedlings. Analyses were performed on subsamples of 45 seedlings per treatment ( 30 for pedunculate oak) in order to homogenise initial sizes. The trial was irrigated by a mist system from April 22 to September 10 . Irrigation was adjusted so that rainfall plus irrigation slightly exceeded potential evapotranspiration (PET) 
estimated by the formula of Turc [39] (table II). The $25-\mathrm{cm}$ upper soil in nursery frames consisted of $2.4 \%$ organic mater, $4.2 \%$ clay, $10.4 \%$ slime and $82.6 \%$ sand with a $\mathrm{pH}$ of 5.8 .

At the end of the second growing season, we measured survival and height of seedlings.

\subsection{Statistical analysis}

Analysis of variance followed by Tukey's HSD test $(p<0.05)$ were used for the effects of lifting date and cold storage treatments on seedling water status, REL and growth. A simple regression analysis (linear model) was used at the individual plant level $(n=63-150)$ to determine the relations between the different pairs of quality variables. For survival, a Chi-square test was performed, with treatments compared by pairs at a $5 \%$ level.

\section{RESULTS}

\subsection{The effects of lifting date and cold storage treatments on water status variables and $R E L$}

In both oak species, all pairs of either water status variables or REL were highly correlated (tables III $a, b$ ). In Corsican pine, some pairs of variables were poorly related (table IIIC), especially REL with all water status variables except $\Psi_{\mathrm{wp}}$. The latter variable was significantly related to all other variables. To facilitate comparisons between species, we focused on bud and root water content: two variables that were measured in all species and treatments and were most sensitive to desiccation in shoots and roots, respectively. Some additional results on $W L$ and $R E L$ were also given.

In the three species, root water content of the non stored seedlings was highest for the November lifting (figure 1). Root water content decreased steadily with increasing desiccation duration and reached, after four

Table II. Potential evapotranspiration (PET) and water supply in the field with reference to the mean weather conditions of the 1969-1996 period.

\begin{tabular}{|c|c|c|c|}
\hline $\begin{array}{l}\text { From April } 1 \\
\text { to September } 30\end{array}$ & in 1997 & in 1998 & $\begin{array}{c}\text { Mean of } \\
1969-1996 *\end{array}$ \\
\hline PET (mm) & 580 & 501 & 551 \\
\hline $\begin{array}{l}\text { Rainfall + } \\
\text { irrigation }(\mathrm{mm})\end{array}$ & 606 & 579 & 336 \\
\hline
\end{tabular}

*Without irrigation. weeks, very low values in both oak species (between 45 to $70 \%$ ) but not in pine (between 130 and 160\%). As compared to the non stored seedlings, root water content after four weeks of desiccation was decreased by $55 \%$ and $31 \%$ in oaks and in pine, respectively. At this stage of desiccation, lowest root water content values were observed in March, for red oak and Corsican pine, and in November for pedunculate oak.

Bud water content of the non stored seedlings was highest for the March lifting (figure 1) except for pedunculate oak. For the four week of desiccation, bud water content decreased in oak species but not in pine. In red oak seedlings the lowest bud water content values $(80 \%$ decrease as compared to the non stored seedlings) after four weeks desiccation were reached in March, whereas no date effect was observed for bud water content in pedunculate oak and in pine.

Plant weight loss was independent of species and lifting date with a mean value of $10 \%$ and $18 \%$ after 2 and 4 weeks, respectively.

In oaks, $R E L$ increased after a 4-week exposure to desiccation, for all lifting dates (figure 2). In pine, REL did not increase with the time of desiccation.

In the three species, bud and root water content and $W L$ remained unchanged when seedlings were stored for 4 weeks in sealed plastic bags (figure 1). This treatment preserved also REL (figure 2).

\subsection{The effects of lifting date and cold storage treatments on post planting performance}

\subsubsection{Survival and height growth in the field}

Survival of non stored controls was higher than $90 \%$, except for red oak lifted in November (table IV). After a four-week exposure to desiccation, survival was below $90 \%$, except for pine lifted in March, and reached minimum values for the November lifting. In red oak, independently of the storage treatments, survival was highest for the January lifting. In pedunculate oak, survival after a four-week desiccation was lowest in November. In pine, survival was not affected by desiccation in gunny bags, except when seedlings were lifted in November and cold stored for four weeks (table IV).

Survival of seedlings stored for four weeks in sealed plastic bags was similar to that of non stored seedlings in both oak species, whatever the lifting date. In constrast, in pine, the seedlings of this treatment displayed lower survival than the non stored seedlings, except in January.

Height growth of the non stored seedlings differed among species (pedunculate oak $>$ pine $>$ red oak) but 
Table III. Simple regression analyses (linear model) between quality variables measured at planting, for (a) northern red oak, (b) pedunculate oak and (c) Corsican pine. For all species: $W L$, weight loss during storage; $W C$, water content; $R E L$, root electrolyte leakage. For pine: $\Psi_{\mathrm{wp}}$, predawn needle water potential; $\pi$, needle osmotic potential; $P$, needle turgor potential. Significance error levels: ns, non significant $(P>0.05)$;,$P<0.05 ; * *, P<0.01 ; * *, P<0.001$.

a) Northern red oak ( $n=106$ to 150$)$.

\begin{tabular}{lcccccc}
\hline & Taproot $W C$ & Shoot $W C$ & Bud $W C$ & Root $W C$ & $W L$ & $R E L$ \\
\hline Relative Root $W C$ & $* * *$ & $* * *$ & $* * *$ & $* * *$ & $* * *$ & $* * *$ \\
$R E L$ & $* * *$ & $* * *$ & $* * *$ & $* * *$ & $* * *$ & \\
$W L$ & $* * *$ & $* * *$ & $* * *$ & $* * *$ & & \\
Root $W C$ & $* * *$ & $* * *$ & $* * *$ & & & \\
Bud $W C$ & $* * *$ & $* * *$ & & & & \\
Shoot $W C$ & $* * *$ & & & & & \\
\hline
\end{tabular}

b) Pedunculate oak ( $n=63$ to 150$)$.

\begin{tabular}{lcccccc}
\hline & Taproot $W C$ & Shoot $W C$ & Bud $W C$ & Root $W C$ & $W L$ & $R E L$ \\
\hline Relative Root $W C$ & $* * *$ & $* * *$ & $* * *$ & $* * *$ & $* * *$ & $* * *$ \\
$R E L$ & $* * *$ & $* * *$ & $* * *$ & $* * *$ & $* * *$ & \\
$W L$ & $* * *$ & $* * *$ & $* * *$ & $* * *$ & & \\
Root $W C$ & $* * *$ & $* * *$ & $* * *$ & & & \\
Bud $W C$ & $* * *$ & $* * *$ & & & & \\
Shoot $W C$ & $* * *$ & & & & & \\
\hline
\end{tabular}

c) Corsican pine $(n=150$ à 129$)$.

\begin{tabular}{|c|c|c|c|c|c|c|c|c|c|}
\hline & Needle $W C$ & Bud $W C$ & Root $W C$ & $W L$ & $\Psi_{\mathrm{wp}}$ & $\pi$ & $P$ & $R E L$ & $\begin{array}{l}\text { Relative } \\
\text { Root } W C\end{array}$ \\
\hline Relative Needle $W C$ & $* * *$ & ns & $* * *$ & $* * *$ & $* * *$ & $* * *$ & $\mathrm{~ns}$ & ns & $* * *$ \\
\hline Relative Root $W C$ & $* * *$ & $* * *$ & $* * *$ & $* * *$ & $* * *$ & $*$ & $* * *$ & ns & \\
\hline$R E L$ & ns & ns & ns & ns & $* *$ & ns & ns & & \\
\hline$P$ & $* *$ & $*$ & ns & $* * *$ & $* * *$ & $* * *$ & & & \\
\hline$\pi$ & $* * *$ & ns & $* * *$ & $*$ & $* * *$ & & & & \\
\hline$\Psi_{w n}$ & $* * *$ & $* *$ & $* * *$ & $* * *$ & & & & & \\
\hline$W L$ & $* * *$ & $* * *$ & $* * *$ & & & & & & \\
\hline Root $W C$ & $* * *$ & ns & & & & & & & \\
\hline Bud $W C$ & ns & & & & & & & & \\
\hline
\end{tabular}

Table IV. Effect of storage conditions and lifting date on survival (\%) two years after outplanting in northern red oak, pedunculate oak and Corsican pine. Mean values not sharing common letters are significantly different at $P=0.05$ (Chi-square test).

\begin{tabular}{|c|c|c|c|c|}
\hline Lifting date & Storage conditions & Northern red oak & Pedunculate oak & Corsican pine \\
\hline $\begin{array}{l}\text { November } \\
18\end{array}$ & $\begin{array}{c}0 \text { week } \\
2 \text { weeks } \\
4 \text { weeks } \\
4 \text { weeks in bags }\end{array}$ & $\begin{array}{l}87 \mathrm{~cd} \\
78 \mathrm{de} \\
64 \mathrm{e} \\
84 \mathrm{~cd}\end{array}$ & $\begin{array}{l}100 \mathrm{a} \\
97 \mathrm{ab} \\
57 \mathrm{c} \\
100 \mathrm{a}\end{array}$ & $\begin{array}{l}93 \mathrm{a} \\
84 \mathrm{ab} \\
71 \mathrm{bc} \\
64 \mathrm{c}\end{array}$ \\
\hline $\begin{array}{l}\text { January } \\
27\end{array}$ & $\begin{array}{c}0 \text { week } \\
2 \text { weeks } \\
4 \text { weeks } \\
4 \text { weeks in bags }\end{array}$ & $\begin{array}{l}96 \mathrm{abc} \\
96 \mathrm{abc} \\
84 \mathrm{~cd} \\
100 \mathrm{a}\end{array}$ & $\begin{array}{l}100 \mathrm{a} \\
100 \mathrm{a} \\
83 \mathrm{~b} \\
100 \mathrm{a}\end{array}$ & $\begin{array}{c}93 \mathrm{a} \\
93 \mathrm{a} \\
82 \mathrm{abc} \\
84 \mathrm{ab}\end{array}$ \\
\hline $\begin{array}{l}\text { March } \\
10\end{array}$ & $\begin{array}{c}0 \text { week } \\
2 \text { weeks } \\
4 \text { weeks } \\
4 \text { weeks in bags }\end{array}$ & $\begin{array}{l}98 \mathrm{ab} \\
89 \mathrm{bcd} \\
73 \mathrm{de} \\
96 \mathrm{abc}\end{array}$ & $\begin{array}{l}97 \mathrm{ab} \\
93 \mathrm{ab} \\
87 \mathrm{~b} \\
93 \mathrm{ab}\end{array}$ & $\begin{array}{l}93 \mathrm{a} \\
93 \mathrm{a} \\
93 \mathrm{a} \\
76 \mathrm{bc}\end{array}$ \\
\hline
\end{tabular}



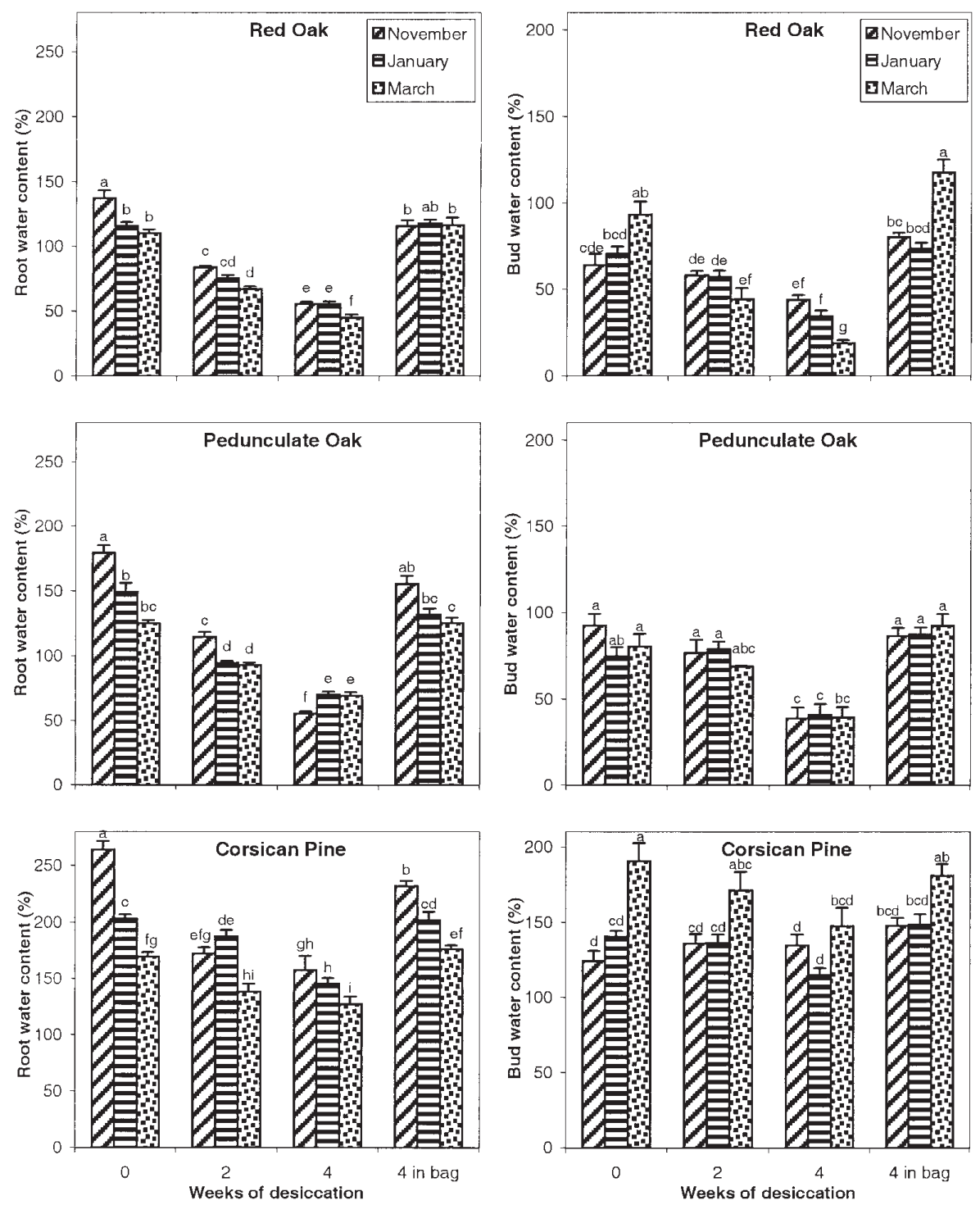

Figure 1. Effect of storage treatments combined with lifting date on seedling physiological variables: root water content (\%); bud water content $(\%)$, in northern red oak, pedunculate oak and Corsican pine. Mean values not sharing common letters are significantly different at $P=0.05$. Bars represent the standard error of each mean.

not on lifting date, except for pedunculate oak in March (lower growth) (figure 3). A four-week exposure to desiccation lowered height growth for all lifting dates in pedunculate oak, and only for the March lifting in red oak and pine. In oaks, some treatments were characterised by negative values of height variation two years after outplanting due to dieback of the main stem.

In the three species, seedling stored in sealed bags did not differ in height growth from the non stored seedlings (figure 3).

\subsubsection{Root growth potential in controlled conditions}

In the non stored seedlings, RGP was lowest for the November lifting in both oak species, whereas there was no difference among dates in pine (figure 3). In pedunculate oak, RGP was clearly highest in March.

When exposed to desiccation for 4 weeks, RGP was decreased in all species and for all lifting dates, with the exception of red oak in March.

In pine, seedlings stored in sealed bags displayed RGP values that were clearly lower than those observed 

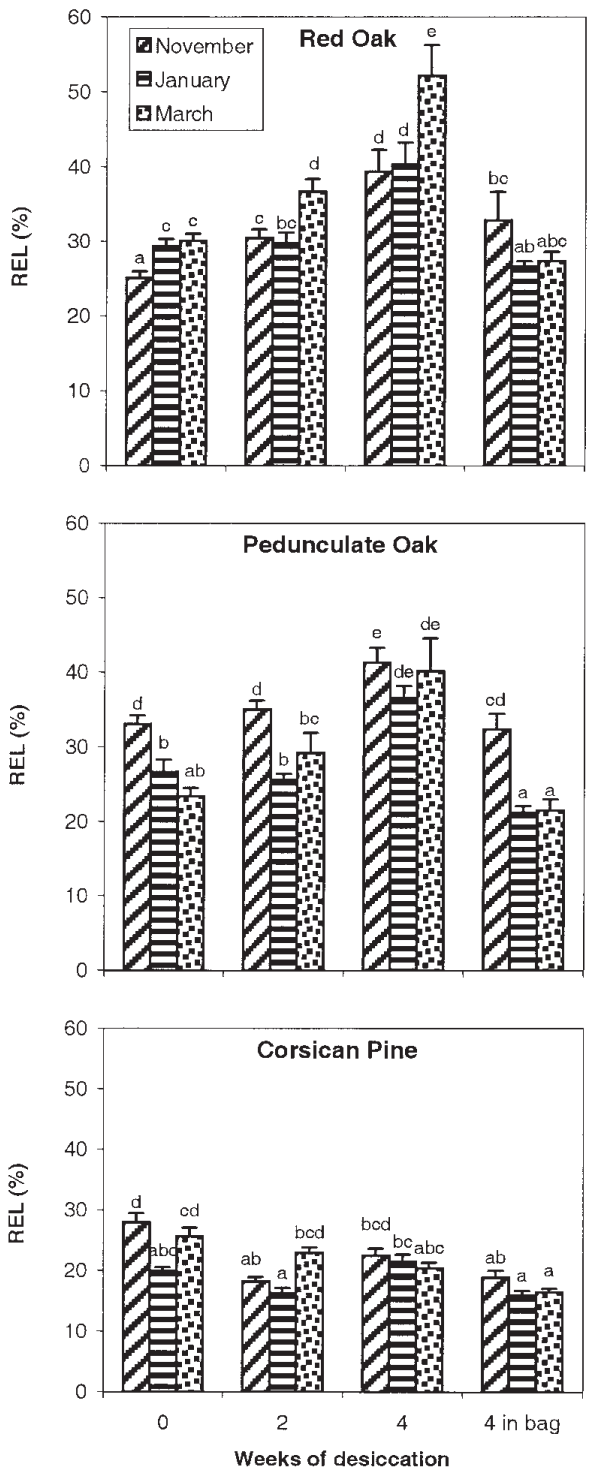

Figure 2. Effect of storage treatments combined with lifting date on $R E L$, root electrolyte leakage (\%), in northern red oak, pedunculate oak and Corsican pine. Mean values not sharing common letters are significantly different at $P=0.05$. Bars represent the standard error of each mean.

for the non stored seedlings, and were identical to those found in the seedlings exposed to desiccation. In oaks, no RGP measures were performed for the seedlings stored in sealed bags.

\subsection{Relationships between field performance and root water content or RGP}

Among the various water status variables and $R E L$, root water content was best related to survival and height variation after outplanting (data not shown). In pedunculate oak, close unique relationships were found between root water content and survival (curvilinear relationship) on the one hand and between root water content and height variation (linear relationship) on the other hand (figure 4). In red oak, curvilinear relationships were found between root water content and both survival and height variation; however a clear date effect appeared for the relationship between root water content and survival. In pine, no relationship was found between root water content and survival, while a loose linear relationship appeared between root water content and height variation.

In both oak species, low RGP values $(<50 \mathrm{~cm})$ were associated with low survival, whereas in pine low RGP were associated with either high or low survival (figure 5). Significant relationships between RGP and height variation were found in none of the three species.

\section{DISCUSSION}

Cold storage affected the water status of unprotected seedlings. Desiccation occurred in all plant components and increased with storage duration, excepted for pine buds (figure 1). In conifers, Coutts [7] and Sucoff et al. [36] found the root system to be most prone to desiccation. The results obtained here for pine, pointing to the absence of bud desiccation during desiccation (figure 1), are consistent with these findings. In contrast, in oaks, buds underwent the same level of desiccation as roots. Girard et al. [12] found red oak buds to be extremely prone to desiccation in a desiccation experiment carried out with seedlings lifted in March. In the present study the extent of bud desiccation was also highest in March for red oak (figure 1).

With the decrease of root water content during exposure, we observed an increase in $R E L$ in both oak species (figure 2). This effect could be related to the degradation of cell membranes [27] due to the desiccation induced by exposure. The increase in $R E L$ was noticed on several broadleaved species including Quercus robur [30]. In pine, $R E L$ did not increase with desiccation intensity (figure 2). This result is not in agreement with results obtained in similar studies with coniferous species [29]. The absence of desiccation effect on REL in pine may be associated here with the lesser extent of root desiccation observed in pine as compared with oaks (figure 1). 

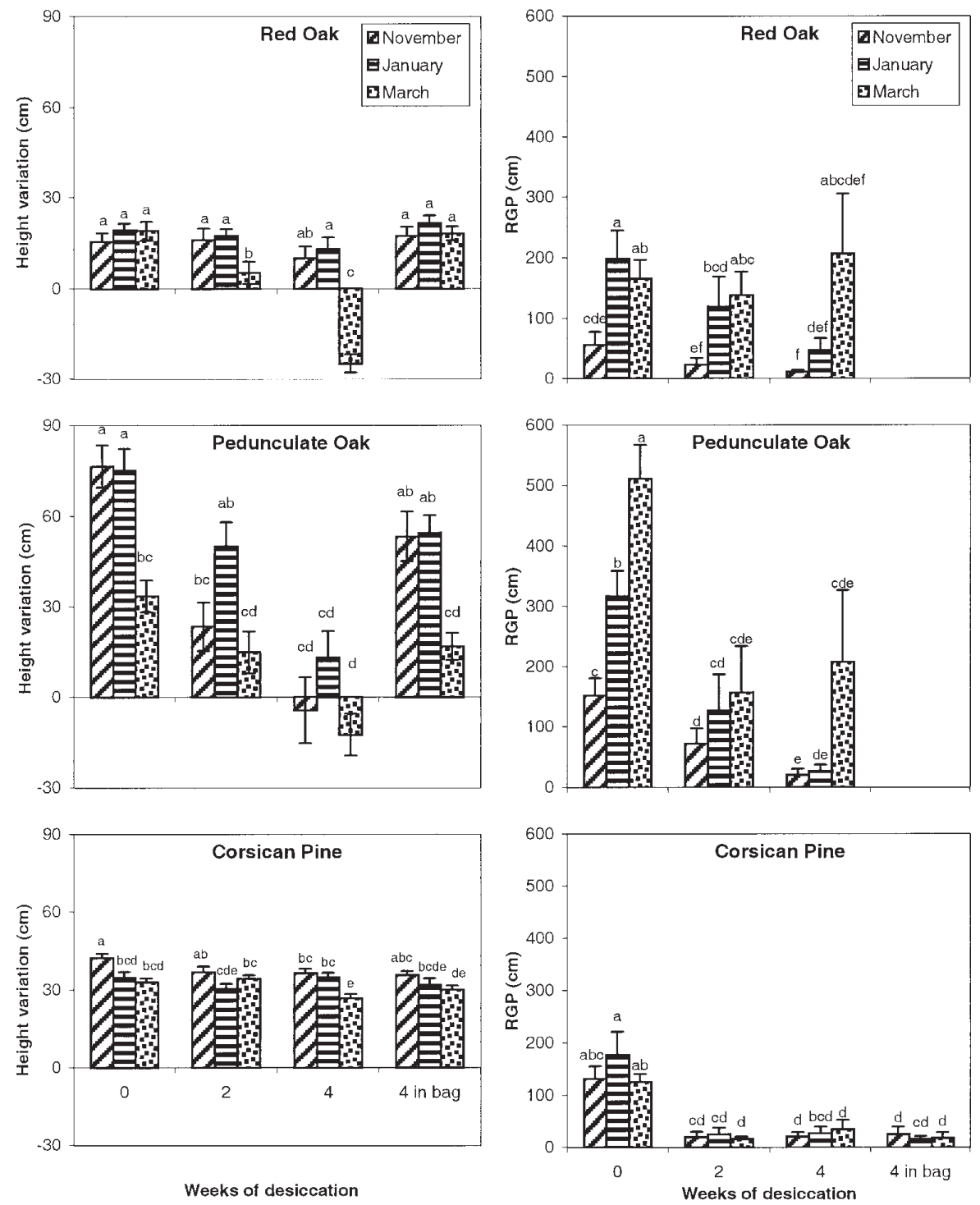

Figure 3. Effect of storage treatments combined with lifting date on growth performance: root growth potential 42 days after transplanting in minirhizotrons and height variation two years after outplanting, in northern red oak, pedunculate oak and Corsican pine. Mean values not sharing common letters are significantly different at $P=0.05$. Bars represent the standard error of each mean.
Exposure to desiccating conditions for four weeks led to decreased survival, height growth or RGP in the three species for all lifting dates (table IV, figure 3). Similar results were obtained in different broadleaved and coniferous species $[10,12,13,41]$. Even though survival was affected by the desiccation treatments in all species, this effect was clearly associated with decreasing root water content in both oak species, whereas it was independent of root water content in pine (figure 4). As it was found elsewhere [34, 41], we found that cold storage in sealed plastic bags prevented from any alteration in plant water status in all species. These conditions led to satisfactory field performance in oaks, as already reported [1, 40]. In pine, survival (table IV) as well as RGP (figure 3) were lowered despite the favourable water status. The factors involved in the decreased performance in pine are still unknown.

Height growth of surviving seedlings over two years after planting was clearly related to water status at planting (figure 4) in the three species. In oaks, negative height growth resulted from bud abortion and shoot dieback $[10,12]$. In our experiment, height growth was most sensitive to desiccation in pedunculate oak, with more severe dieback than in red oak (figure 4 ). 

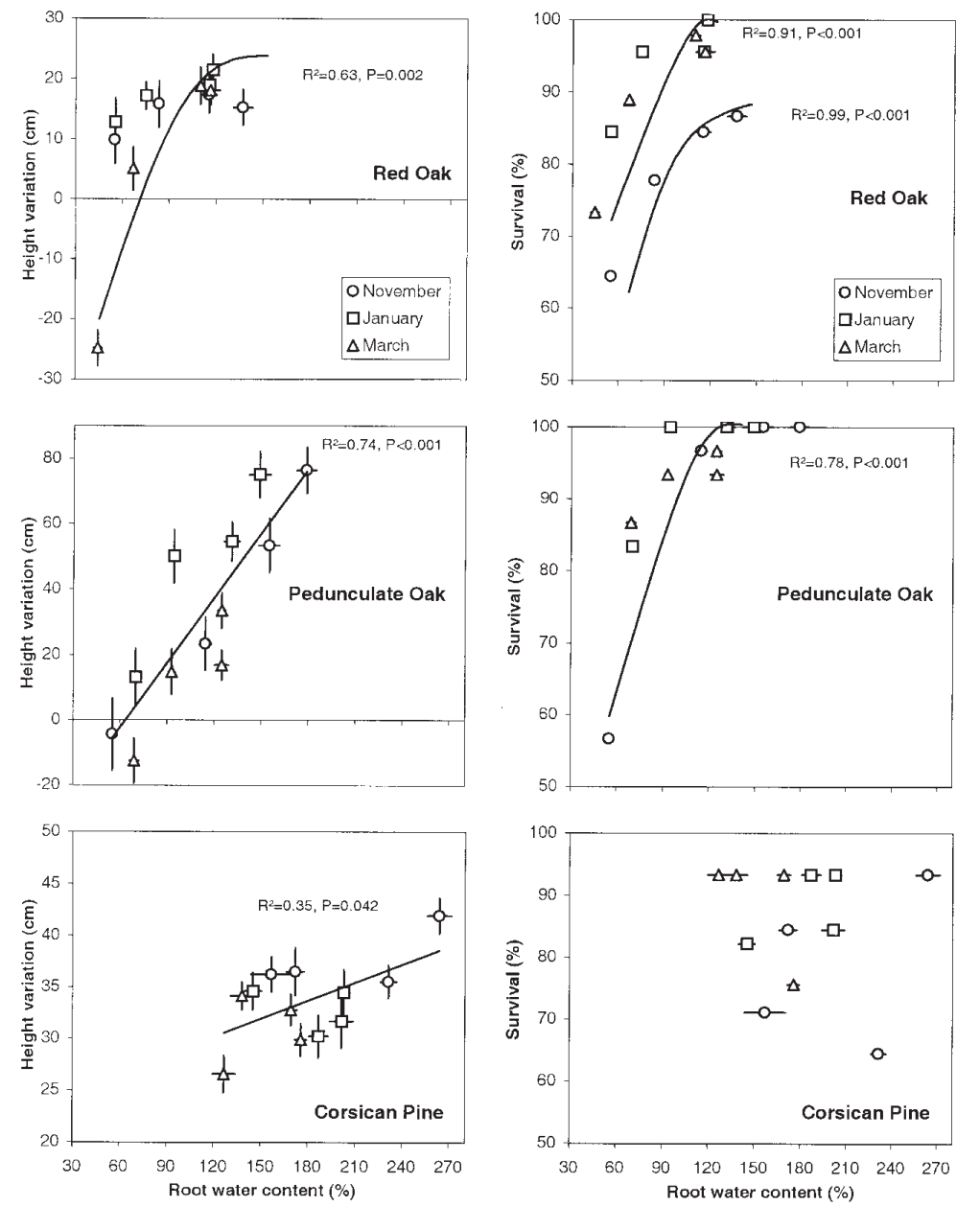

Figure 4. Relationships between root water content and field performance (height variation and survival) after two years, in northern red oak, pedunculate oak and Corsican pine. The three lifting dates were represented by different symbols. Data points denote mean values \pm 1 standard error of the mean.

Measuring vulnerability to embolism in twigs of mature trees in these two oak species, Cochard et al. [6] found a reverse trend. In Corsican pine, after a 192-hour exposure under ambient conditions at $8^{\circ} \mathrm{C}$, Girard et al. [13] showed a loss of hydraulic conductivity in xylem conduits, when $\Psi_{\text {wp }}$ fell below $-4 \mathrm{MPa}$. In our experiment, $\Psi_{\mathrm{wp}}$ remained clearly above this threshold after 4 weeks of desiccation $(-0.5$ to $-0.3 \mathrm{MPa})$. This could explain why height growth did not decrease with desiccation, except slightly for the 4-week exposure in March.

The seedling sensitivity to desiccation displayed differences among lifting dates. In the three species, survival was most affected by the four-week of desiccation in November (table IV), whereas height variation was most affected for the March lifting (figure 3). This confirm results observe on Pseudotsuga menziesii lifted at three different date during winter, and with better survival and growth after desiccation in January [17]. The low survival found in pedunculate oak for the four-week of desiccation in November was linked to the pronounced root desiccation observed in this treatment (figure 4). In contrast, in red oak and pine, the low survival found for the same desiccation conditions in November was not associated with a pronounced desiccation status. Differences among lifting dates in the sensitivity to desiccation have been related to the intensity of dormancy in Douglas fir [32] and in Sitka spruce [7].

Several quality variables and RGP have been used to predict field performance of seedlings exposed to desiccation. The relationship between RGP and field performance was not obvious here, as already noticed by Sharpe and Mason [34]. The discrepancy between RGP and field performance observed here may be attributed to the different environmental conditions following outplanting along the lifting season. We obtained satisfactory relationships between field performance variables (survival and height growth) and root water content, especially in oaks. Different authors have found clear 

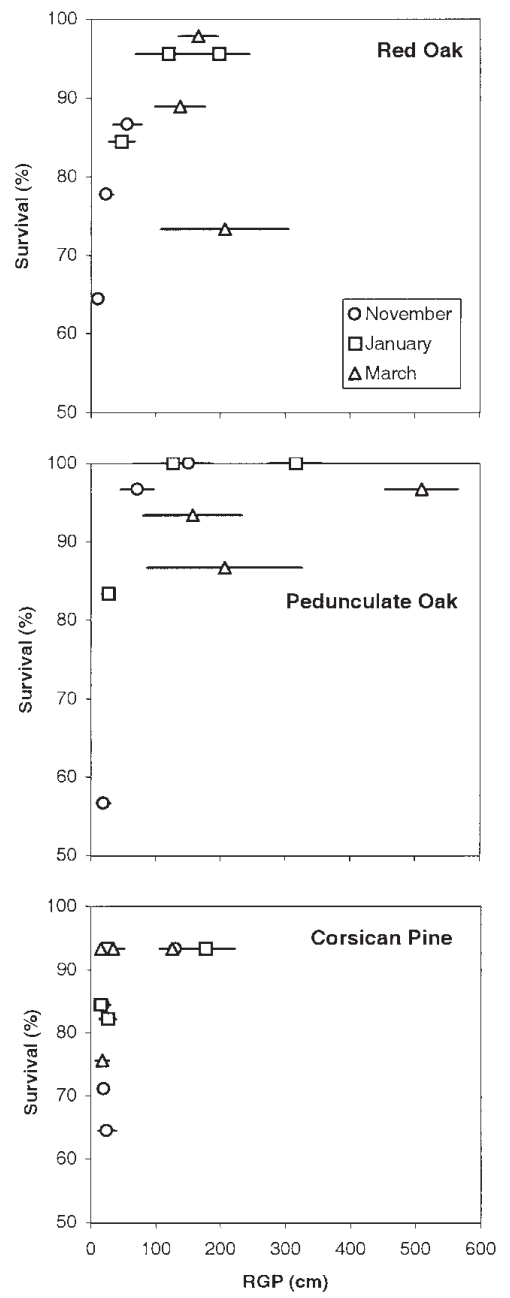

Figure 5. Relationships between root growth potential (RGP) measured in controlled conditions and survival after two years, in northern red oak, pedunculate oak and Corsican pine. The three lifting dates were represented by circles for November, squares for January and triangles for March. Bars represent the standard error of each mean.

relationships between various water contents of seedlings and subsequent survival or growth performance $[8,18,34,37]$. Root electrolyte leakage, a variable that is related to cell membrane integrity, has been suggested to be a good predictor of field performance [ 9 , $27,37]$. In our study $R E L$ in oaks was closely related to root water content and field performance. In pine, however, $R E L$ did not prove useful for predicting field performance.

From a practical point of view, a four-week exposure to desiccation in the cold store adversely affected planti- ng stock quality and performance. Seedling desiccation was the factor primarily involved in the decreased plant quality. This result points to the importance of protecting seedlings from desiccation e.g. in sealed polythene bags from lifting. The results we obtained for pine show that storage in confined conditions may lead to reduced seedling quality independently of any alteration in water status. Further investigations are needed to elucidate the factors involved in such effects. Our results also show that plant water status variables are simple and relevant predictors of field performance in the case of exposure of seedlings under desiccation conditions.

Acknowledgments: The authors wish to thank the European Commission for having provided funds to conduct that research within contract FAIR 1 No. 95-0497 and the European partners for their collaborations. The contribution of "Conseil Régional de Bourgogne" and "Pépinières Naudet" was also greatly appreciated. We are also grateful to the people who were involved in the practical work and in the follow up of the current thesis.

\section{REFERENCES}

[1] Aldhous J.R., Cold storage of forest nursery plants. An account of experiments and trials; 1958-63, Forestry 37 (1964) 47-63.

[2] Aussenac G., El Nour M., Évolution du potentiel hydrique et du système racinaire de jeunes plants de cèdre, pin laricio de Corse et pin noir plantés à l'automne et au printemps, Ann. Sci. For. 43 (1986) 1-14.

[3] Bernier P.Y., Comparing natural and planted black spruce seedlings. I. water relations and growth, Can. J. For. Res. 23 (1993) 2427-2434.

[4] Burdett A.N., Physiological processes in plantation establishment and the development of specifications for forest planting stock, Can. J. For. Res. 20 (1990) 415-427.

[5] Camm E.L., Goetze D.C., Silim S.N., Lavender D.P., Cold storage of conifer seedlings: an update from the British Columbia perspective, Forestry Chronicle 70 (1994) 311-316.

[6] Cochard H., Bréda N., Granier A., Aussenac G., Vulnerability to air embolism of three european oak species (Quercus petraea (Matt) Liebl, $Q$ pubescens Willd, $Q$ robur $\mathrm{L}$ ), Ann. Sci. For. 49 (1992) 225-233.

[7] Coutts M.P., Effects of root or shoot exposure before planting on the water relations, growth, and survival of sitka spruce, Can. J. For. Res. 11 (1981) 703-709.

[8] Deans J.D., Lundberg C., Tabbush P.M., Cannell M.G.R., Sheppard L.J., Murray M.B., The influence of desiccation, rough handling and cold storage on the quality and establishment of Sitka spruce planting stock, Forestry 63 (1990) 129-141.

[9] Dunsworth B.G., Impact of lift date and storage on field performance for douglas-fir and western helmlock, in: Proceedings, combined meeting of the western forest nursery 
association, Vernon, British Columbia, August 8-11 (1988) 199-206.

[10] Englert J.M., Warren K., Fuchigami L.H., Chen T.H.H., Antidesiccant compounds improve the survival of bare-root deciduous nursery trees, J. Am. Soc. Horticult. Sci. 118 (1993) 228-235.

[11] Généré B., Les facteurs influencant la qualite physiologique des plants plantés, et la prise en compte des risques climatiques après plantation, R. F. F. 49 (1997) 313-323.

[12] Girard S., Clément A., Boulet-Gercourt B., Guehl J.M., Effects of exposure to air on stress in red oak seedlings, Ann. Sci. For. 54 (1997) 395-401.

[13] Girard S., Clément A., Cochard H., Boulet-Gercourt B., Guehl J.M., Effects of desiccation on post-planting stress in bare-root Corsican pine seedlings, Tree Physiol. 17 (1997) 429435.

[14] Grossnickle S.C., Planting stress in newly planted jack pine and white spruce. 1. Factors influencing water uptake, Tree Physiol. 4 (1988) 71-83.

[15] Grossnickle S.C., Black T.J., Acclimatation of coldstore jack pine and white spruce seedlings: effects of soil temperature on water relation patterns, Can. J. For. Res. 15 (1985) 544-550.

[16] Haase D.L., Rose R., Soil moisture stress induces transplant shock in stored and unstored $2+0$ douglas-fir seedlings of varying root volumes, For. Sci. 39 (1993) 275294.

[17] Hermann R.K., Seasonal variation in sensitivity of douglas-fir seedlings to exposure of roots, For. Sci. 13 (1967) 140149.

[18] Insley H., Damage to broadleaved seedlings by desiccation, Arboricultural Advisory and Information Service, Arboriculture research note 8 (1979) p. 4.

[19] Insley H., Buckley G.P., The influence of desiccation and root pruning on the survival and growth of broadleaved seedlings, J. Horticult. Sci. 60 (1985) 377-387.

[20] Kaushal P., Aussenac G., Transplanting shock in Corsican pine and cedar of Atlas seedlings: internal water deficits, growth and root regeneration, For. Ecol. Manag. 27 (1989) 29-40.

[21] Lindström A., Nyström C., Seasonal variation in root hardiness of container-grown Scots pine, Norway spruce and lodgepole pine seedlings, Can. J. For. Res. 17 (1987) 787-793.

[22] Margolis H.A., Brand D.G., An ecophysiological basis for understanding plantation establishment, Can. J. For. Res. 20 (1990) 375-390.

[23] Mattsson A., Predicting field performance using seedling quality assessment, New Forests 13 (1997) 227-252.

[24] McCreary D.D., Durya M.L., OSU vigor test; principles, procedures and predictive ability, In Evaluating seedling quality, Durya M. (Ed.), Oregon State Univ., Corvallis, Oregon, 1985, p. 86.

[25] McEvoy C., McKay H., Sensitivity of broadleaved trees to desiccation and rough handling between lifting and transplanting, Arboricultural Advisory and Information Service, Arboriculture research and information note 139 (1997) p. 7.
[26] McEvoy C., McKay H., Root frost hardiness of amenity broadleaved seedlings Arboricultural Journal 21 (1997) 231244.

[27] McKay H.M., Electrolyte leakage from fine roots of conifer seedlings: a rapid index of plant vitality following cold storage, Can J. For. Res. 22 (1992) 1371-1377.

[28] McKay H.M., A review of the effect of stresses between lifting and planting on nursery stock quality and performance, New Forests 13 (1997) 369-399.

[29] McKay H.M., White I.M.S., Fine root electrolyte leakage and moisture content: Indices of Sitka spruce and Douglasfir seedling performance after desiccation, New Forests 13 (1997) 139-162.

[30] McKay H.M., Jinks R.L., McEvoy C., The effect of desiccation and rough-handling on the survival and early growth of ash, beech, birch and oak seedlings, Ann. Sci. For. 56 (1999) 391-402.

[31] Omi S.K., Yoder B., Rose R., Fall lifting and long-term freezer storage of ponderosa pine seedlings: effects on poststorage leaf water potential, stomatal conductance, and root growth potential, Tree physiol. 8 (1991) 315-325.

[32] Ritchie G.A., Relationships among bud dormancy status, cold hardiness, and stress resistance in $2+0$ Douglas-fir, New Forests 1 (1986) 29-42.

[33] Sands R., Transplanting stress in radiata pine, Australian Forest Research 14 (1984) 67-72.

[34] Sharpe A.L., Mason W.L., Some methods of cold storage can seriously affect root growth potential and root moisture content and subsequent forest performance of Sitka spruce and Douglas fir transplants, Forestry 65 (1992) 463-472.

[35] Stone E.C., Jenkinson J.L., Krugman S.L., Root regeneration potential of douglas-fir seedlings lifted at different times of the year, For. Sci. 8 (1962) 288-297.

[36] Sucoff E., Buschena C., Tamte P., Desiccation and water potentials in the roots, leaves, and shoots of bare-root red pine and white spruce, Can. J. For. Res. 15 (1985) 989-992.

[37] Symeonidou M.V., Buckley P.G., The effect of preplanting desiccation on survival and growth of Prunus cerasifera seedlings and the relationship of physiological indicators at planting with field performance and survival, Russian J. Plant Phys. 44 (1997) 514-517.

[38] Tabbush P.M., Effect of desiccation on water status and forest performance of bare-rooted Sitka spruce and Douglas fir transplants, Forestry 60 (1987) 31-43.

[39] Turc L., Évaluation des besoins en eau d'irrigation, évapotranspiration potentielle : formule climatique simplifiée et mise à jour, Ann. Agron. 12 (1961) 3-49.

[40] von Althen F.W., Webb D.P., Overwinter cold storage of hardwood nursery stock: effects on outplanting performance, Proceedings of Northeastern Area Nurserymen's Conference, Springfield, Missouri, August 10-13, (1981) 20-33.

[41] Webb D.P., von Althen F.W., Storage of hardwood planting stock: effects of various storage regimes and packaging methods on root growth and physiological quality, N. Z. J. For. Sci. 10 (1980) 83-96. 